IZA DP No. 7918

The Relationship between Federal Budget

Amendments and Local Electoral Power

Sergio Firpo

Vladimir Ponczek

Viviane Sanfelice

January 2014 


\title{
The Relationship between Federal Budget Amendments and Local Electoral Power
}

\author{
Sergio Firpo \\ Sao Paulo School of Economics - FGV \\ and IZA \\ Vladimir Ponczek \\ Sao Paulo School of Economics - FGV \\ Viviane Sanfelice \\ University of Rochester
}
Discussion Paper No. 7918
January 2014

IZA

P.O. Box 7240

53072 Bonn

Germany

\author{
Phone: +49-228-3894-0 \\ Fax: +49-228-3894-180 \\ E-mail: iza@iza.org
}

\begin{abstract}
Any opinions expressed here are those of the author(s) and not those of IZA. Research published in this series may include views on policy, but the institute itself takes no institutional policy positions. The IZA research network is committed to the IZA Guiding Principles of Research Integrity.

The Institute for the Study of Labor (IZA) in Bonn is a local and virtual international research center and a place of communication between science, politics and business. IZA is an independent nonprofit organization supported by Deutsche Post Foundation. The center is associated with the University of Bonn and offers a stimulating research environment through its international network, workshops and conferences, data service, project support, research visits and doctoral program. IZA engages in (i) original and internationally competitive research in all fields of labor economics, (ii) development of policy concepts, and (iii) dissemination of research results and concepts to the interested public.
\end{abstract}

IZA Discussion Papers often represent preliminary work and are circulated to encourage discussion. Citation of such a paper should account for its provisional character. A revised version may be available directly from the author. 
IZA Discussion Paper No. 7918

January 2014

\section{ABSTRACT}

\section{The Relationship between Federal Budget Amendments and Local Electoral Power}

The objectives of this paper are twofold. First, we investigate whether politicians use resources from the federal budget as a strategy to maintain and expand their political capital. Second, we examine whether such a strategy is rewarded by voters who elect politicians who assist their municipalities through federal expenditures. The main contribution of this study is its illustration of how the use of fiscal policy affects the local political power of legislators in Brazil. We focus on the geographical distribution of votes received by politicians within their electoral districts instead of only examining the final outcomes of reelection efforts. Our findings indicate that politicians tend to favor municipalities that were important to their elections and that voters support candidates who have brought resources to their localities. However, given that Brazil uses a party-open-list proportional representation system for congressional elections, influencing the behavior of voters through amendments is not sufficient to increase a candidate's chances of winning reelection.

JEL Classification: $\quad \mathrm{H} 7$

Keywords: $\quad$ voter's preference, pork barrel, politician's strategies, electoral power

Corresponding author:

Sergio Firpo

Escola de Economia de São Paulo - FGV-SP

R. Itapeva, 474/1215

São Paulo 01332-000

Brazil

E-mail: sergio.firpo@fgv.br 


\section{Introduction}

The empirical literature has established that incumbent politicians have certain advantages in elections. Fiscal policy has typically been the channel used by incumbents to influence voters in elections for executive branch offices. The literature on pork-barrel politics has documented that, under district-based electoral systems, public expenditures are an important mechanism used by legislators to canvass voters. Brazil does not use a single member per district electoral system to elect members to its Chamber of Deputies, the house of Congress that most closely resembles the U.S. House of Representatives. Given these characteristics of the structure of the system, the major objectives of this paper are $(i)$ to investigate whether incumbent congressional politicians use fiscal policy as a strategy to obtain voter support in Brazil and $(i i)$ to determine whether this strategy is electorally effective. In particular, we assess the relationship between amendments to the federal budget and the electoral outcomes for deputies who propose such amendments. Thus, the main contribution of this paper is to show how the use of fiscal policy affects the local political power of legislators in Brazil. Toward this end, we focus on the geographical distribution of votes received by politicians within their electoral districts instead of exclusively examining the success or failure of candidates' reelection efforts.

One possible means of influencing voters that has been investigated in the literature is the manipulation of public deficits, a practice that results in electoral cycles of public spending. However, Brender and Drazen (2008), analyzing a sample of 74 countries over a 43-year period, find no evidence that public deficits increase the reelection chances of executive branch members. Indeed, their results show that in developed democracies, the effect is negative, i.e., voters punish politicians who increase budget deficits. Shelton (2012) argues that the institutionalization of the party system is associated with the mitigation of political budget cycles. With respect to Brazil, Sakurai and Menezes-Filho (2008) note that expenditures in election years tend to reduce the chances of reelection of local executive incumbents, whereas expenditures in non-election years appear to benefit incumbents. Thus, increases in fiscal outlays do not appear to be an efficient means of retaining local executive positions. Nevertheless, voters may have preferences regarding the composition of expenditures but not necessarily regarding the total amount spent. In several countries, increases in expenditures targeted at investment and reductions in existing expenditures have been found to have positive effects $1^{1}$ Meneguin, Bugarin and Carvalho (2005) demonstrate that voters in Brazilian municipalities tend to disapprove cost expenditures and support investment expenditures, which are electorally visible. In this way, fiscal manipulation can occur through alternative means that do not involve the incursion of public budget deficits, as voters' choices may be based on the composition and/or distribution of budgetary resources. The legislative branch cannot determine total expenditures as flexibly as the executive branch can. Thus, the use of fiscal policy by legislators for electoral purposes often occurs via the distribution of resources through amendments to the budget. Representatives

1 See Katsimi and Sarantides (2012), Khemani (2004) and Peltzman (1992). 
can focus on a specific group of voters and generate benefits for this group at the expense of other groups. In the literature focusing on U.S. politics, this practice is known as pork-barrel legislation, a procedure whereby incumbents use government programs to distribute funds to geographically specific groups in exchange for political support via campaign contributions or votes. Whereas the benefits of this spending are restricted to specific locations, all taxpayers pay for these initiatives ${ }^{2}$

In the U.S., pork-barrel legislation can be observed through agricultural subsidies and engineering projects (e.g., the construction of roads). Most studies focused on the U.S. have shown connections between benefits that flow to a region and support for a specific congressperson in an election ${ }^{3}$ Leigh (2008) notes a similar phenomenon for Australia $4^{4}$ Similarly to the system in the U.S., in Australia, one member is chosen to represent each electoral district. Given this type of electoral structure, there is a direct connection between a politician and a given region, as each location elects its own representative.

However, this connection is not well documented in countries where legislative races occur in electoral districts with large geographical dimensions and where various parties/candidates are elected within single, multimember districts. The Brazilian example provides an opportunity for a case study, as the country utilizes a party-open-list proportional representation system for congressional elections. Given this structure, it is unclear whether there are incentives for deputies to use fiscal policy to target geographically specific groups of voters. Nevertheless, as shown by Ames (1995a and 1995b) in his analysis of the Brazilian system, informal electoral districts that are smaller than the formal districts within which they are located may exist. In these more concentrated environments, politicians can focus their efforts and eventually be rewarded by the support of voters. According to Latner and McGann (2005), candidates are influenced by two major considerations when seeking regional representation in a system with multiple representatives per district. In terms of electoral competition, it might be advantageous for a party to have candidates running for election in different regions, as this maximizes the total number of votes won by the party. Moreover, internal party competition can stimulate the regionalization of candidates, preventing two candidates that represent the same party from competing for the same voters.

In Brazilian congressional elections, voters cast single ballots either for party labels or individual candidates, and parties can form election party coalitions. The numbers of individual votes that candidates receive determine the ranking of candidates in a party coalition list. The D'Hondt method is used to determine the number of seats each coalition obtains. Electoral districts in Brazil consist of the 27 individual states, which elect specific numbers of representatives according to the sizes of their populations. Once elected, amendments to the federal budget are the key tool that representatives can use to assign federal resources to the specific

\footnotetext{
2 The pork-barrel literature, which began with Mayhew (1974), is quite extensive. A list of studies, including some of the most notable contributions, can be found in Bickers et al. (2007).

3 See, for example, Fiorina (1981), Cain, Ferejohn and Fiorina (1987) and Stein and Bickers (1994).

4 See Costa-i-Font et al. (2003) for pork-barrel politics in Mexico and Golden and Picci (2008) for Italy.
} 
regions in which they have vested electoral interests. The amendments proposed by deputies concern changes to the Draft Budget Law (Projeto de Lei Orçamentária, henceforth referred to as PLO), drawn up by the executive branch.

It is important to examine why voters engage in backward-looking behavior, i.e., why they care about what a candidate did in a previous term, instead of forward-looking behavior, whereby voters would consider a candidate's future projects to be pursued during his/her next term in office. In this regard, Drazen and Eslava (2006) propose a theoretical model in which voters infer future benefits based on the value received by their district during the politician's previous term in office. In this model, it is assumed that politicians have unobservable preferences for locations and that these preferences persist over time. Therefore, a voter who believes he/she received some benefit during an incumbent's previous term will expect similar expenditures following reelection. Drazen and Eslava's (2006) theoretical results show that, given informational asymmetry, if voters are affected by public funds, these past expenditures will increase the number of votes received by the incumbent, a bonus that will occur even if the electorate is aware of the politician's electoral interests. In addition, the same results indicate that incumbents should focus their efforts on groups of voters that are more easily influenced before elections.

Some studies seek to associate the composition of the Brazilian budget with the political interests of deputies. More precisely, such studies attempt to determine the relationship between amendments and electoral performance 5 Nonetheless, there is no consensus regarding whether amendments contribute to an increase in the probability of a deputy's reelection. Furthermore, with the exception of Ames (1995a and 1995b), these studies assess the aggregate outcomes for candidates within electoral districts. Consequently, there is no method for directly measuring the relationship between regionally assigned funds and local political returns for incumbents.

The present paper uses local electoral results to study the causes and consequences of the actions of federal deputies. To investigate this process, we explore the relationship between amendments to the federal budget that are directed to specific municipalities and the local electoral outcomes of candidates running for the Brazilian Chamber of Deputies. This study focuses on the 50th, 51st, 52nd and 53rd legislative sessions of Congress and five elections for the Chamber of Deputies (1994, 1998, 2002, 2006 and 2010) ${ }^{6}$

This paper analyzes two questions in detail. The first addresses whether politicians tend to "bring home the bacon". We show that municipalities that are able to elect candidates who are "associated" with their voters receive an increased share of the federal budget 7 This dynamic occurs because deputies tend to allocate resources to localities that have provided them with electoral support in previous elections. We exploit a

\footnotetext{
5 Some examples include Ames (1995), Pereira and Rennó (2003), Samuels (2002) and Mesquita (2008).

6 The 50th, 51st, 52nd and 53rd legislative sessions correspond to the years 1995-98, 1999-2002, 2003-06 and 2007-10, respectively.

7 In the following sections, we provide a precise definition of the association between candidates and municipalities.
} 
discontinuity in the election rule for Congress, one that guarantees exogenous variation in the number of elected deputies linked to (or associated with) given municipalities. We show that this effect is stronger in localities where political concentration is more pronounced. By using a regression discontinuity design, we overcome the concern that the unobservable characteristics of candidates and municipalities would be systematically related to both electoral performance and the capabilities of candidates to propose amendments.

These findings contribute to the "electoral targeting" literature, a literature that considers ways in which politicians allocate resources to maximize their electoral outcomes. Two main models are used to debate this issue. On the one hand, Cox and McCubbins's (1986) "core voter model" suggests that candidates allocate resources mainly to their core voters, as such voters should be especially responsive to transfers. On the other hand, Lindbeck and Weilbull's (1987) "swing voter model" suggests the opposite practice, that is, that candidates target swing voters because their core voters will not punish them.

The empirical literature shows mixed results. Some studies support the swing voter logic (Schady 2000; Dahlberg and Johanson 2002; Stokes 2005), whereas others align with the core voter model (Calvo and Murillo 2004; Hiskey 2003, Levitt and Snyder 1995). Our results support the "core voter model," as deputies are found to be prone to allocate resources to the specific localities that have voted for them in the past.

The second question assessed in this paper is whether voters support incumbent candidates who have proposed the amendments applied to their regions. Employing longitudinal data to control for fixed, unobserved characteristics of candidates and municipalities, we find that deputies who "bring home the bacon" are electorally rewarded in the municipalities that benefit from the candidates' actions. However, because electoral districts are much larger than municipalities, this local effect is not significant enough to increase the reelection chances of such deputies, an outcome that accords with the findings of previous results based on aggregated data.

In summary, the main objective of this paper is to unveil the relationship between votes and local public spending by dissecting two specific perspectives - that of the voters and that of the politicians. The empirical strategies used in this study allow us to determine, under weak assumptions, whether voters react to public spending in their municipalities. We can also determine whether politicians use the electoral preferences associated with these local public goods and services as a strategy to win reelection.

The paper proceeds as follows. In the next section, we discuss the underlying institutional background, with particular emphasis on the mechanics of the Brazilian budget process. The subsequent section describes the datasets used in this paper and presents descriptive statistics regarding the personal, political and electoral characteristics of Brazilian federal deputies and the attributes of federal budget amendments. Section four, entitled Empirical Strategies, discusses the identification strategies used in this paper to estimate voters' preferences and politicians' reactions to these preferences. Our findings are interpreted in section five, and a final section offers our conclusions. 


\section{Institutional Background: The Mechanics of the Brazilian Federal Budget Process}

The Brazilian annual federal budget has three main parts: the fiscal budget, social insurance and investments in public companies. The executive branch plans the fiscal budget, which is the component of the overall budget in which revenues are estimated and expenditures are directed. Congress may propose changes to the draft budget through amendments. These amendments may originate from rapporteurs of the budget draft, the congressional budget commission or individual deputies and senators. The resources needed to fund amendments must come from the cancellation of expenditures that are already provided for in the budget proposed by the executive branch. Ongoing expenditures, which include staff payments, debt charges and constitutional tax transfers to states and municipalities, cannot be cut. Indeed, only investment expenditures are subject to reallocation, and these correspond to approximately $3 \%$ of total expenditures (Mesquita 2008).

The congressional budget commission (Comissão Mista do Orçamento) is responsible for analyzing the executive's budget proposal in the Congress. This committee is composed of 30 deputies and 10 senators, who choose a general rapporteur and 10 sectoral rapporteurs from among their members 8 Since 1995, institutional changes have decentralized the power of budget draft rapporteurs, facilitating the access of federal deputies to the budget. At the same time, to guarantee a more uniform distribution of funds among deputies, the number of amendments per deputy was limited to 20 , and the maximum value that can be utilized was set at $\mathrm{R} \$ 1.5$ million per deputy per year ${ }^{9}$ In 2010 , the maximum value was raised to $\mathrm{R} \$ 12.5$ million, and the number of amendments was increased to 25 per deputy per annual budget 10

Deputies show interest in the funds allocated through amendments and spend most of their time seeking approval for these initiatives (Samuels 1998; Figueiredo and Limongi 2002). Each amendment must be individually approved by the budget commission (by majority), and the entire fiscal budget (including all amendments) must be approved by a majority in Congress. However, even approved amendments are not necessarily guaranteed allocation because the executive branch makes final decisions regarding the execution of these measures. This process implies that the executive branch possesses a direct means of influencing individual deputies, thus increasing its base of support in Congress without the need for political parties as intermediaries.

Funds from budget amendments can be allocated to national, regional, state or local (municipal) programs. From 1995 to 2002, more than $60 \%$ of the total value of amendments implemented went to projects at the municipal level. After 2002, this number fell to less than $30 \%$. With respect to local amendments, it is common knowledge that a deputy is free to allocate these measures to any Brazilian municipality, including municipalities outside his/her state (electoral district). Nonetheless, if the politician's goal is to maximize the number of votes he/she receives in a reelection race, we can expect that deputies would prefer to allocate amendments to the

\footnotetext{
8 The sectors from which rapporteurs can be chosen are as follows: health, education, justice, environment, urban development, agriculture, social assistance, tourism, infrastructure and representation.

9 This rule came into effect in 1996 during the preparation of the budget plan executed in 1997.

10 This value corresponds to approximately U.S.\$ 7.1 million. The annual average exchange rate in 2010 was 1.76 BRL/USD.
} 
municipalities within the states they represent. Indeed, of the total number of individual amendments executed from 1996 to 2007 , only $1.29 \%$ of these initiatives were allocated to municipalities outside the state in which the deputy who proposed them was elected. In the same period, accounting only for local amendments proposed by deputies who were running for reelection, only $1.02 \%$ of amendments were allocated to localities outside the states that the politicians who secured them represented. These numbers reinforce the notion that deputies view budgetary resources as playing an important role in wooing voters and therefore direct a majority of amendments to municipalities located in their electoral districts.

\section{Data and Definitions}

The data used in this paper come from two different sources. Data on votes, the electorate and candidates were obtained from the Superior Electoral Court (TSE). Data related to the federal budget, specifically regarding the implementation of amendments to the federal budget, were acquired from the Brazilian Chamber of Deputies. Information on the political history of candidates was also collected from this source. Our study examines four budget cycles (1995-1999, 1999-2003, 2003-2007 and 2007-2011) $\sqrt{11}$ and five Brazilian elections for the Chamber of Deputies (1994, 1998, 2002, 2006 and 2010).

The following subsections introduce several important concepts that help to clarify the characteristics of candidates and municipalities and the factors affecting amendments and votes. In our study, candidates and/or municipalities are treated as the unit of analysis.

\subsection{Definitions}

Two "effective number" variables are formulated based on the inverse Herfindahl-Hirschman Index (HHI). The number of effective candidates, which is a variable at the municipality level, is used mainly to capture competition within a municipality, and the number of effective municipalities, a variable at the candidate level, measures the degree of dispersion of a candidate's voting across municipalities 12

We also define a variable that allows us to identify candidates who are associated, from the voters' perspective, with a given municipality. First, for each municipality, we rank the candidates based on the

11 The budget execution for 2011 was not used, as it had not been completed when the data were collected.

12 The formulas used to calculate the number of effective municipalities and the number of effective candidates are, respectively,

$$
\text { MunEfet }_{i t}=\left(\sum_{m=1}^{\# M u n i_{s t}}\left(\frac{v_{i m t}}{\sum_{m=1}^{\# M u n i} v_{i m t}}\right)^{2}\right)^{-1}
$$

and

$$
\text { CandEfet }_{m t}=\left(\sum_{i=1}^{\# \text { Cand }_{s t}}\left(\frac{v_{i m t}}{\sum_{i=1}^{\# C a n d_{s t}} v_{i m t}}\right)^{2}\right)^{-1} .
$$


number of votes they receive. We then identify the candidates who received the largest number of local votes and associate them with municipalities based on the number of effective candidates in a given municipality, i.e.

$$
\text { Assoc }_{\text {imt }}=1\left\{r_{i m t} \leq \text { CandE }_{\text {fet }} \text { mt }\right\}
$$

where $i$ indicates the candidate, $m$ indicates the municipality and $t$ indicates the election. The variable $r$ represents the rank of candidate $i$ in municipality $m$ and thus equals one for the candidate with the most votes, two for the candidate with the second most votes and so on; $1\{\cdot\}$ is an indicator function equal to one if its argument is true and zero otherwise. Thus, association with a given municipality is a dichotomous variable indicating whether candidate $i$ is among the effective candidates (CandEfet) in municipality $m$.

We note the similarity between our concept of association and Ames's (1995b) notion of dominance. Candidate $i$ 's municipal dominance in municipality $m$ is a continuous variable, as it simply represents candidate $i$ 's share of all the votes cast in municipality $m$ (Ames, 1995b). Given that municipalities may differ in terms of voter concentration, the measure of dominance varies from one municipality to another. For example, in a given municipality, a candidate with $10 \%$ of the vote might be a highly dominant candidate. In other municipalities, a $10 \%$ share of the vote may have a different meaning because voter dispersion across candidates may differ across municipalities. However, association is a concept that allows us to compare the electoral performance of given candidates across different municipalities because if a candidate is associated with a given municipality $m$, he/she has a relatively high share of votes in $m$.

\subsection{Federal Deputies}

A total of 513 Chamber of Deputies seats are allocated in each election. Table 1 shows the characteristics of elected federal deputies from 1994 to 2006 that will be analyzed in this paper.

\section{[Insert Table 1 here]}

As shown in Table 1, approximately three-quarters of elected deputies run for the same office in the subsequent election ${ }^{13}$ This group of politicians differs, to some extent, from those who do not run for reelection in terms of the percentage of nominal votes obtained in their electoral districts and the realized value of amendments. Deputies who did not run in subsequent elections received, on average, more votes in their electoral districts than candidates who did run and were less involved in proposing amendments to the federal budget. It is possible that politicians who decide not to participate in subsequent elections are the individuals most likely to be absent from the Chamber of Deputies and therefore least likely to amend the budget. A

\footnotetext{
13 The reelection rate calculated by the authors is based on TSE data.
} 
second explanation, not pursued in this paper, is that because these politicians are not interested in reelection, they may not use amendments as public policy.

The sample used to analyze the effect of amendments on electoral outcomes consists of deputies who run for reelection, an approach that could raise concerns about sample selection bias. On the one hand, it is possible that the deputies who decide not to run for reelection are less likely to receive the votes needed to be reelected. In this case, the sampling procedure would upwardly bias our estimates of the impact of amendments on votes. On the other hand, it is possible that deputies who decide not to seek reelection are those with more political capital, which is used to run for higher offices (e.g., senator, state governor, mayor of a large city or state capital) or even to be appointed to important positions in the executive branch (minister, secretary, CEO of a state-owned firm, etc.). In this alternative interpretation, the selection procedure would downwardly bias our estimates.

Table 2 provides information about municipalities. As shown in the table, the average number of effective candidates in a given municipality is approximately six, whereas the number of associated candidates who are successfully elected is approximately four. The total monetary value of budgetary amendments per voter is roughly $\mathrm{R} \$ 30$ (in 2010 values), a value that decreases over the course of electoral terms. The average size of the electorate is approximately 20,000 voters.

\section{[Insert Table 2 here]}

\subsection{Amendments to the Budget}

In this paper, we consider only amendments that succeeded (that is, those that were approved and executed) and were proposed by an individual elected federal deputy and targeted to municipalities in the candidate's electoral district ${ }^{14}$ The monetary value of an amendment is recorded in the budget data as paid (liquidado), an amount that is subject to adjustment so that the total amount does not exceed the initial value established by the deputy. When a deputy alters an existing project by adding funding, the total value of the amendment is the sum of all of the amounts allocated to the project. In this case, we consider the initial endowment allocated by a politician to an amendment to identify the value attributable to the deputy.

Table 1 indicates the average amount of an amendment proposed by federal deputies, and Table 2 reports the amounts obtained by municipalities as a result of these actions. Most of the amendments allocated to a given municipality come from politicians who are associated with that municipality ${ }^{15}$ However, amendments are also

\footnotetext{
14 We also constructed a database for the budget period from 2002 to 2011 to enable us to consider all amendments proposed by deputies, including amendments that were not necessarily approved and executed. The findings, which are available upon request, are as expected. Proposed amendments that were not executed exhibit smaller or insignificant coefficients with respect to electoral returns.

15 We provide supplementary tables and figures in the online Appendix. These figures are included in Table A.1 in the Appendix.
} 
allocated to municipalities in which a politician who secures an amendment is not among the candidates with the most votes. Federal deputies not only allocate benefits to municipalities that previously provided electoral support for them but also use amendments to obtain voter support in other cities. As we will show below, the latter strategy has a larger effect on electoral success.

\section{Empirical Strategies}

\subsection{Allocation of Individual Budget Amendments}

One of the objectives of this paper is to assess how local amendments are distributed among municipalities within a deputy's electoral district. Therefore, let us consider the following equation:

$$
y_{i m t}=\beta_{0}+\beta_{1}^{\top} X_{i m t}+\beta_{2}^{\top} C_{i t}+\beta_{3}^{\top} M_{m t}+c_{t}+c_{m}+c_{i}+\epsilon_{i m t}
$$

where $i$ indicates an individual federal deputy, $m$ indicates the municipality and $t$ is a time indicator that represents both the election in which the deputy obtained office and the politician's term in office. The variables $c_{t}, c_{m}$ and $c_{i}$ denote fixed effects at the level given by the associated subscript, and $\epsilon_{i m t}$ is the error term. The dependent variable, $y_{i m t}$, is the value of individual amendments per voter in municipality $m$ proposed by politician $i$ in period $t$. Vector $X$ contains explanatory variables that vary jointly by deputy and municipality. However, some variables, such as the percentage of nominal votes obtained in a municipality and the coincidence of the deputy's party and the mayor's party, change over time. Nevertheless, some variables that do not change during electoral terms pertain to a politician's previous local political history within a municipality. Vector $M$ denotes municipality variables, such as the number of effective candidates in the municipality. Vector $C$ includes descriptive characteristics of politicians, for example, gender, previous political experience in other positions (for the specifications that we do not include in $c_{i}$ ), the number of effective municipalities with which the deputy is associated during elections and the number of previous terms of the politician.

Equation 2 is estimated using ordinary least squares (OLS), the fixed-effects (FE) model and the Tobit model, assuming that the per voter value of amendments is censored at zero.

The fixed-effects approach is consistent when fixed unobservable characteristics of both deputies and municipalities are present. However, changes over time in individual and municipality characteristics that are related to electoral outcomes may bias the results. For example, an exogenous shock may boost a municipality's economy in a given period, motivating increased electoral donations by citizens and firms to the incumbent deputy and, in turn, inducing the latter to propose more individual amendments for that municipality. To overcome this problem, we also implement a regression discontinuity design approach, which is robust to the presence of unobservable shocks that are not fixed over time. 


\subsection{Regression Discontinuity Design (RDD)}

We use the discontinuity that arises from open-list proportional representation rules whereby candidates from a given party coalition may be either elected or not by a small margin of votes. Lee (2008) applies discontinuous regression to determine the electoral advantages of incumbents in U.S. Congressional elections. Eggers et al. (2013) analyze elections in countries other than the U.S., finding that random assignment induced by the discontinuity does not appear to hold for the U.S. but is found in mayoral races in other countries, including Brazil. Most applications of the regression discontinuity design to elections that follow Lee's approach focus on single-member districts. However, a recent paper by Boas, Hidalgo and Richardson (2011), which uses an approach similar to ours, is an exception to this practice.

In elections for the Chamber of Deputies, each constituent votes either for one candidate or for a particular political party. However, seats are distributed to party coalitions according to a D'Hondt formula, and candidates are then ranked according to the number of votes they receive in the state, with seats distributed to candidates within the electoral party/coalition based on that ranking. Therefore, in a given election, between two candidates from the same party/coalition who are within a fixed and narrow margin of votes, random chance may determine that one candidate is elected while the other is not.

Because this discontinuity is a candidate characteristic, we take average values for candidates across the municipalities with which they are associated. Thus, we average the amount of budget amendment spending across each candidate's associated municipalities and simply calculate the differences in such averages between elected and non-elected candidates whose vote tallies fall within a narrow margin of one another.

Finally, by comparing municipalities that have the same numbers of effective candidates, we can check whether those with larger numbers of elected associated candidates receive increased transfers of budget resources. By only considering municipalities whose associated candidates won or lost by small margins ${ }^{16}$ we can obtain the degree of randomness needed in the number of elected associated candidates at the municipal level.

We compare municipalities that have the same numbers of effective candidates and thus the same electoral competition structures. Therefore, in some cases, we compare a municipality with an associated candidate on the margin who was elected with another municipality with an associated candidate on the margin who was not elected. Thus, we seek to determine whether the first municipality will obtain more transfers via amendments to the budget as a result of electing its candidate. In other words, we test whether an elected candidate associated with a municipality contributes to the allocation of budget resources. We expect that deputies within the margin should be, on average, very similar, with the only important difference being that

16 Surrogates are treated as not elected, despite the possibility that these candidates will eventually be sworn in as federal deputies. Thus, the results are likely to underestimate the effect of having an elected candidate associated with a municipality based on the value of local amendments received. 
one was elected, whereas the other was not. Note that the same reasoning applies to deputies' respective associated municipalities. Within a narrow margin of votes, these deputies should be, on average, very similar. The only difference between candidates' respective associated municipalities is that one had its associated candidate elected and the other did not.

To determine the margin of votes in a proportional representation system, in which each candidate is either elected or not according to the total number of votes received by the coalition party rather than the total number of votes received by the candidates themselves, the following mechanism was utilized: for each party/coalition, in each electoral district (state), we considered the total number of nominal votes received by the elected candidate with the least number of votes and the votes of the candidate who was not elected with the largest number of votes. The simple average of the votes of these two candidates was used as a reference. If, in absolute terms, the difference between a candidate's votes and the average was smaller than a given percentage of that average - for instance, $5 \%$ - the candidate was said to be within the margin; otherwise, he/she was not. For example, consider two candidates from the same party/coalition, where one is the elected candidate with the least number of votes (e.g., 105,000 votes) and the other is the non-elected candidate with largest number of votes (e.g., 95,000 votes). In this case, the average number of votes of both candidates is 100,000. Therefore, these candidates would be within the margin of $5 \%$, as the difference from the average $(5,000)$ is $5 \%, 17$

We first check whether candidates have similar characteristics. Table 3 lists the characteristics of candidates for the Chamber of Deputies, including the elected, the non-elected and those candidates whose votes fell within a narrow margin. If candidates on the margin won or lost due to random chance, no differences in their preelection characteristics should be observable. In fact, there are substantial differences in the characteristics of candidates who do not fall within the narrow margin; however, those variations disappear when we compare candidates within the margin, especially within a range of $2.5 \%$. Additionally, if electing a candidate associated with a given municipality by a narrow margin of votes is a random event, we should not observe differences between municipalities that have $n$ or $n+1$ elected associated candidates. Indeed, Table 4 shows that there are no significant differences between the means of certain variables at the municipality level.

\section{[Insert Table 3 here]}

[Insert Table 4 here]

\footnotetext{
17 We opted for a selection of candidates by a relative margin of victory rather than an absolute victory because, under a proportional system that includes several parties/coalitions, there are substantial discrepancies in voter profiles among elected and non-elected deputies across parties/coalitions.
} 
We then check whether there is any pooling of candidates on either side of the discontinuity. In fact, there is no evidence of manipulation across sides ${ }^{18}$ We performed a visual version of McCrary's (2008) test for differences in densities across the discontinuity and found no evidence of this type of effect.

\subsection{Electoral Returns from Individual Budget Amendments}

In the second model tested, amendments are treated as an explanatory variable. The model is used to investigate whether the distribution of budget resources to municipalities through pork barrel legislation is a technique used to appeal to Brazilian voters. The model to be tested is as follows:

$$
y_{i m, t+1}=\beta_{0}+\beta_{1} X_{i m t}+\beta_{2} C_{i t}+\beta_{3} M_{m t}+c_{t}+c_{m}+c_{i}+\epsilon_{i m t}
$$

where $i$ now refers to the federal deputy who runs for reelection and $y$ represents the nominal votes obtained by deputy $i$ in municipality $m$.

Note that votes in $t+1$ are observed only for deputies who run for reelection and that the value of budgetary resources allocated to a given municipality by a politician during his/her term is among the explanatory variables. In this case, we also include joint deputy-municipality fixed effects $\left(c_{i m}\right)$ for those specifications that do not separately consider deputy or municipal fixed effects.

\section{Results}

\subsection{Allocation of Individual Budget Amendments}

According to our results, shown in Table 5, the votes received in a given municipality strongly affect a politician's decision to allocate local amendments to that municipality, confirming the notion that politicians tend to reward their voters. An increase in vote shares within a municipality by one percentage point elevates the amount of resources allocated via individual budget amendments by approximately $\mathrm{R} \$ 38$ per voter. For example, an average municipality has roughly 20,000 voters, and candidates generally have $2.2 \%$ of local votes. Thus, on average, a candidate gains 440 votes per municipality. This pattern would imply that $\mathrm{R} \$ 16,720$ is allocated by the deputy to that municipality. This value corresponds to approximately $4 \%$ of the total monetary value that a municipality receives, on average, through amendments, results that support Cox and McCubbins's (1986) "core district" theory that politicians target their "pork" to key supporters.

[Insert Table 5 here]

18 See Figure A.1 in the Appendix. 
One interesting finding is that the larger the number of effective municipalities in which the deputy runs, the smaller the value of the amendments allocated to a given municipality is. In other words, deputies with more dispersed votes often allocate smaller amounts to each municipality. The strategy of such politicians may be to split funds among a larger number of municipalities so that the value allocated to each municipality is smaller. Another result is that the number of effective candidates in a given municipality appears to reduce the transfer of funds in some of our models. Nevertheless, when we take into account the fixed effects of the municipality, the coefficient of this variable is not significant. This result suggests that changes in local electoral competition in a given municipality do not affect the amount of allocated transfers.

The results support the idea that, in general, candidates tend to provide benefits to municipalities in which they have received large numbers of votes and to which they have some type of connection, e.g., they have held other political positions in the past or belong to the mayor's party. One implication that can be derived from these observations is that deputies tend to provide benefits to municipalities where they have obtained larger numbers of votes but that politicians with more dispersed votes reduce the value transferred by amendments to specific municipalities. Given this allocation problem faced by politicians, an advantageous strategy for voters in a municipality seeking pork would be to vote for traditional local candidates whose influence covers relatively small regions. Thus, the creation of informal districts would be advantageous to voters. This notion suggests that the demand side may drive Ames's (1995a) classical interpretation of the lack of interest exhibited by politicians in national issues. In other words, deputies are constrained by their constituents' demand for increases in their share of federal resources.

To corroborate the previous findings, we propose exploring a discontinuity generated by the electoral rules, a setting in which the electoral outcomes for some candidates may be influenced by random chance. The number of elected candidates associated with a given municipality thus has an exogenous source of variation.

We initially select candidates who won or lost elections by narrow margins, as variations in the numbers of representatives in the Chamber of Deputies for municipalities whose associated candidates fall within the stipulated margin will exhibit pure randomness. The aim is to determine whether municipalities that elected larger numbers of associated candidates by chance are granted greater value of amendments.

The results obtained by exploiting the discontinuity in the rules of the proportional representation system corroborate our previous findings. As shown in Table 6, the larger the number of elected candidates associated with a given municipality, the greater are the resources assigned to the municipality, a result that holds for all selected margins. This evidence appears to be stronger in municipalities with smaller numbers of effective candidates, although the difference across samples is not significantly different from zero. In a municipality characterized by fierce electoral competition, the addition of an elected candidate does not contribute to the allocation of funds. However, in municipalities where competition is milder, the presence of an elected candidate strongly influences the allocation of amendments. In this case, having an elected candidate associated with the 
municipality increases the value obtained from individual amendments by approximately $\mathrm{R} \$ 6$ per voter (the difference between the coefficients is significant at the $10 \%$ level for a margin of $2.5 \%$ ).

\section{[Insert Table 6 here]}

It is important to note that the RDD strategy has an important limitation with respect to the external validity of the exercise. The analysis is valid for the subset of municipalities with associated candidates who won elections by relatively narrow margins, but little can be concluded about the effects on other municipalities, such as those whose associated candidates won by wide margins. We note, however, that the RDD findings are very similar to those obtained using a different identification strategy, namely, panel data with fixed effects. It is also important to note that this alternative identification strategy, unlike RDD, does not rely on the subset of elected deputies who barely won their elections.

In general, we conclude that there is clear evidence that elected deputies tend to "bring home the bacon," especially when they are greatly dominant locally. Local electoral competition appears to create incentives for deputies to pursue new voters because when local competition is relatively intense, municipalities tend to benefit less.

\subsection{Local Electoral Returns of Individual Budget Amendments}

After assessing the behavior of deputies with respect to allocations of amendments, our next objective is to examine how such funds affect the electoral prospects of politicians as candidates for reelection. Therefore, the sample is now restricted to elected federal deputies who ran for reelection in subsequent periods. The objective is to investigate the impact on the number of votes received by a politician in a municipality that receives funds through an individual amendment allocated by a given candidate. The next subsection will focus on deputies' reelection outcomes, i.e., on whether the amendments they secured improved their reelection prospects.

As shown in Table 7, the allocation of amendments increases the number of nominal votes received in a municipality by a politician in charge of the budgeting project.19 The "amendment per voter" variable measures the total value of amendments per voter suggested by a deputy throughout the budget cycle during his/her term. The coefficient for this variable is positive and significant in all tested models. A deputy's past relationship with a municipality influences the number of votes he/she receives, showing, among other things, that voters are loyal to politicians. Thus, the number of votes that a politician previously received in a municipality explains much about the current number of votes the politician receives, and by not controlling for

\footnotetext{
19 We use nominal votes instead of the proportion of votes within municipalities because the electoral district is the state, which is composed of several municipalities. Therefore, from the candidate's perspective, nominal votes in a municipality are directly related to his/her electoral success.
} 
a deputy's electoral strength within a municipality, we have an omitted variable problem. Given that politicians allocate amendments to municipalities in which their political support is relatively strong, as outlined above, the role that amendments play at the ballot box is likely to have been overestimated. By controlling for deputy-municipality fixed effects, previous connections between a politician and the municipality are taken into account. Consequently, the coefficient for the "amendments per voter" explanatory variable decreases, allowing us to more accurately estimate the effects of amendments on deputies' electoral prospects. The variable squared has a negative coefficient, indicating that the return in votes gained decreases beyond a given value of per voter total transfers. When deputy-municipality fixed effects are added, the coefficient drops to six votes per $\mathrm{R} \$$ transferred to voters. In conclusion, we find that, for example, in an average municipality with 20,000 voters, an allocation of $\mathrm{R} \$ 200,000$ in budget amendments would supply a candidate with approximately 59 additional votes. This amount is not very impressive when we consider that the average number of votes received by an elected candidate is approximately 80,000. If we consider that the average amount allocated by deputies through amendments is $\mathrm{R} \$ 4$ million (See Table 1 ), the number of votes gained would be 870 , which represents $4 \%$ of the local electorate.

\section{[Insert Table 7 here]}

By dividing funds used in budget amendments into two categories - those allocated to municipalities whose deputy was one of the effective candidates in the previous election and those allocated to municipalities where the politician had no association - we can more deeply investigate the electoral returns resulting from amendments. Based on the coefficients obtained, it is advantageous for politicians to allocate amendments in both types of municipalities. However, allocations of funds to municipalities that do not constitute a deputy's electoral "backyard" more strongly affect nominal votes than allocations of funds to municipalities with which politicians are associated (5.37 compared with 7.37, respectively; the difference is statistically significant at the $5 \%$ level). This finding implies that investments in voters who have not previously been wooed result in higher electoral returns than applications of amendments in municipalities whose deputies are already supported by most of the electorate. In the theoretical model devised by Drazen and Eslava (2006), budget and political cycles will exist if the returns from amendments vary according to groups of voters. As shown by our results, the application of amendments in municipalities that politicians have not yet won delivers greater electoral benefits.

Therefore, electoral amendments are useful in generating nominal votes for incumbent deputies seeking reelection. This effect is even greater when such amendments are used in municipalities that do not represent the deputy's electoral "backyard". As a result, such amendments can serve as an effective tool for canvassing votes in regions where the electorate has not yet been courted. However, the "power" of these resources, in terms 
of their actual ability to generate votes, is small. This relatively minimal effect is reflected in the reelection chances of federal deputies.

\subsection{Amendments and Reelection Outcome}

Given that amendments influence the local electoral performance of deputies, it is interesting to assess whether they are also important in politicians' final electoral outcomes. Thus, using aggregate data per deputy, we investigate the extent to which the allocation of amendments to the budget contributes to a candidate's reelection. The objective is to determine whether amendments are important in guaranteeing politicians' careers as federal deputies. The dependent variable is the success or lack of success of a deputy in his/her reelection efforts.

Using aggregate data, recent studies by Mesquita (2008) and Samuels (2002) have found no evidence of a relationship between amendments and the success of deputies in subsequent elections. Similarly, our results show that, although amendments serve as a tool to achieve local dominance, they are not significant in the reelection process. As shown in Table 8, few variables are relevant in explaining a politician's reelection. In the first model, the total number of locally allocated amendments has a positive and slightly significant coefficient, i.e., amendments increase a politician's likelihood of reelection. However, this variable loses significance when the quadratic term is added. When amendments are categorized by whether a candidate is associated with a municipality, we find that resources provided to localities where associations exist generate a positive effect, although the effect is not significant. In contrast, amendments applied to a municipality not associated with a candidate appear to reduce a candidate's likelihood of reelection, although we previously found that such a strategy increases the number of votes a candidate receives within that electorate. In fact, given that the quadratic term has a positive coefficient, the strategy of distributing resources in such municipalities will not help a deputy win reelection if the amount distributed is less than $\mathrm{R} \$ 11.5$ per voter (the total value of local amendments divided by the total number of voters in the electoral district). Only $3 \%$ of deputies allocated more than this amount during the most recent term. Therefore, we may conclude that the strategy of allocating amendments to municipalities that are not associated with a deputy improves the deputy's reelection chances when the amount spent per voter is sufficiently large.

\section{[Insert Table 8 here]}

Therefore, although amendments are valuable tools in wooing regional voters, they do not appear to be crucial to electoral success. Various political strategies are available to candidates, and a candidate's profile likely has a strong influence on his/her success as a legislator. Our results accord with Ames's (1995b) conjecture 
that reelection may not be a deputy's career goal, and running for a local executive position may be more appealing.

In this sense, federal deputies may have leverage in local elections, as amendments are an important tool for increasing local dominance.

\section{Conclusions}

The main objective of this paper has been to assess the factors that affect allocations of individual amendments to municipalities by federal deputies and to examine whether invested funds influence the electoral performance of incumbents running for reelection. To achieve this goal, several empirical strategies have been adopted. Our results indicate that previous votes received by a politician in a municipality significantly affect the number of amendments to the budget allocated to the municipality by the politician. This is not the only electoral strategy adopted by representatives, but we can conclude that politicians do reward their voters in this way. The adoption of this strategy by Brazilian politicians accords with Cox and McCubbins's (1986) "core voter model".

A discontinuous regression was used to further investigate the allocation of amendments to municipalities. Our results indicate that the effects examined depend on the level of electoral competition within a given municipality. In municipalities with few candidates with effective votes, elected effective candidates contribute generously with allocations of funds. A secondary contribution of this paper is its analysis of the possible mechanisms that influence the number of votes a deputy receives. As expected, amendments to the budget positively affect the nominal votes received by a deputy in a municipality that benefits from his/her allocation of funds. We observe that amendments assigned to areas outside a politician's electoral "backyard" more strongly impact local electoral performance. This result is obtained by classifying municipalities into regions in which a deputy is an effective candidate and those where he/she is not.

Nonetheless, in analyzing the importance of amendments to the electoral success of federal deputies, we cannot confirm that allocations of these benefits increase incumbents' reelection chances. Thus, supplying funds through federal budgets is part of the relationship between a candidate and the municipality and may be an important electoral tool for canvassing votes. However, this practice is not a determining factor in a politician's ultimate electoral success.

Acknowledgements Sergio Firpo and Vladimir Ponczek thank CNPq for research grants and Viviane Sanfelice thanks CAPES for a Master fellowship. 


\section{References}

Ames, B. (1995a). Electoral rules, constituency pressures, and pork barrel: bases of voting in Brazilian Congress. The Journal of Politics, 57(2), 324-343.

Ames, B. (1995b). Electoral strategy under open-list proportional representation Congress. American Journal of Political Science, 39(2), 406-433.

Bickers, K. N., Evans, R., Stein M. \& Robert D. W. (2007). The electoral effect of credit claiming for pork barrel projects in Congress. Presented at the workshop on elections and distribution, Yale University.

Boas, T. C., Hidalgo F. D. \& Richardson N. P. (2011). The spoils of victory: campaign donations and government contracts in Brazil. Working paper Boston University.

Brender, A., \& Drazen, A. (2008). How do budget deficits and economic growth affect reelection prospects? Evidence from a large panel of countries. American Economic Review, 98(5), 2203-2220.

Cain, B., Ferejohn, J. \& Fiorina M. (1987). The personal vote: constituency service and electoral independence. Cambridge: Harvard University Press.

Calvo, E. \& Murillo, V. (2004). Who delivers? Partisan clients in the Argentine electoral market. American Journal of Political Science, 48(4), 742-757.

Costa-i-Font, J., Rodriguez-Oreggia, E., \& Lunapla D. (2003). Political competition and pork-barrel politics in the allocation of public investment in Mexico. Public choice, 116(1-2), 185-204.

Cox, G. \& McCubbins, M. (1986). Electoral politics as a redistributive game. Journal of Politics, 48(May), $370-389$.

Dahlberg, M. \& Johansson, E. (2002). On the vote-purchasing behavior of incumbent governments. American Political Science Review, 96(1), 27-40.

Drazen, A. \& Eslava, M. (2006). Electoral manipulation via voter-friendly spending: theory and evidence. NBER working paper 12190.

Eggers, A., Folke, O., Fowler, A., Hainmueller, J., Hall, A. \& Snyder, J. (2013). On the validity of the regression discontinuity design for estimating electoral effects: new evidence from over 40,000 close races. Unpublished manuscript.

Fiorina, M. (1981). Some problems in studying the effects of resource allocation in congressional elections. American Journal of Political Science, 25(3), 543-567.

Golden, M. \& Picci, L. (2008). Pork-barrel politics in postwar Italy: 1953-94. American Journal of Political Science, 52(2), 268-289.

Hiskey, J. (2003). Demand based development and local electoral environments in Mexico. Comparative Politics, 36(1), 41-60. 
Katsimi, M. \& Sarantides, V. (2012). Do elections affect the composition of fiscal policy in developed, established democracies? Public Choice, 151(1-2), 325-362.

Khemani, S. (2004). Political cycles in a developing economy: effect of elections in the Indian states. Journal of Development Economics, 73, 125-154.

Latner, M., \& McGann, A. (2005). Geographical representation under proportional representation: the cases of Israel and the Netherlands. Electoral Studies, 24(4), 709-734.

Lee, D. (2008). Randomized experiments from non-random selection in U.S. House elections. Journal of Econometrics, 142, 675-697.

Leigh, A. (2008). Bringing home the bacon: an empirical analysis of the extent and effects of pork-barreling in Australian politics. Public Choice, 137, 279-299.

Levitt, S. \& Snyder, J. (1995). Political parties and the distribution of federal outlays. American Journal of Political Science, 39(4), 958-980

Limongi, F. \& Figueiredo, A. (2002). Incentivos eleitorais, partidos e política orçamentária. Dados - Revista de Ciências Sociais, 45(2), 303-344.

Lindbeck, A. \& Weibull, J. (1987). Balanced budget redistribution and the outcome of political competition. Public Choice, 52, 273-297.

Mayhew, D. (1974). Congress: The electoral connection. New Haven: Yale University Press.

McCrary, J. (2008). Manipulation of the running variable in the regression discontinuity design: A density test. Journal of Econometrics, 142, 698-714.

Meneguin, F., Bugarin, M. and Carvalho, A. (2005). O que leva um governante à reeleição? Instituto de Pesquisa Econômica Aplicada Discussion Paper 1135.

Mesquita, L. (2008). Emendas ao orçamento e conexão eleitoral na Câmara dos Deputados brasileira. Ph.D. Thesis, Universidade de São Paulo.

Peltzman, S. (1992). Voters as fiscal conservatives. Quarterly Journal of Economics, 107(2), 327-261.

Pereira, C. \& Renno, L. (2003). Successful re-election strategies in Brazil: the electoral impact of distinct institutional incentives. Electoral Studies, 22(3), 425-448.

Sakurai, S. \& Menezes-Filho, N. (2008). Fiscal policy and reelection in Brazilian municipalities. Public Choice, 137(1-2), 301-314.

Samuels, D. (1998). Political ambition in Brazil, 1945-95: theory and evidence. Presented at the Annual Meeting of the American Political Science Association, Chicago.

Samuels, D. (2002). Pork barreling is not credit claiming or advertising: campaign finance and the sources of personal vote in Brazil. The Journal of Politics, 64(3), 845-863.

Schady, N. (2000). The political economy of expenditures by the Peruvian Social Fund (FONCODES), 1991-95. American Political Science Review, 94(2), 289-304. 
Shelton, C. (2012). Legislative budget cycles. Public Choice, 1-25, forthcoming.

Stein, R. \& Bickers, K. (1994). Congressional elections and the pork barrel. Journal of Politics, 56(2), 377-399.

Stokes, S. (2005). Perverse accountability: a formal model of machine politics with evidence from Argentina. American Political Science Review, 99(3), 315-325. 
Table 1 Overall characteristics of elected deputies by their reelection pursuit status.

\begin{tabular}{|c|c|c|c|c|}
\hline & All & $\begin{array}{l}\text { Not seeking } \\
\text { reelection }\end{array}$ & $\begin{array}{l}\text { Seeking } \\
\text { reelection }\end{array}$ & Diff. \\
\hline Seeking reelection & $\begin{array}{c}0.75 \\
(0.44)\end{array}$ & & & \\
\hline $\begin{array}{l}\text { Percentage of votes in electoral } \\
\text { district }\end{array}$ & $\begin{array}{c}0.03 \\
(0.08)\end{array}$ & $\begin{array}{c}0.04 \\
(0.00)\end{array}$ & $\begin{array}{c}0.03 \\
(0.00)\end{array}$ & $\begin{array}{c}0.01^{* * *} \\
(0.00)\end{array}$ \\
\hline Number of effective municipalities & $\begin{array}{c}12.74 \\
(13.12)\end{array}$ & $\begin{array}{l}12.30 \\
(0.03)\end{array}$ & $\begin{array}{l}12.89 \\
(0.01)\end{array}$ & $\begin{array}{l}-0.59 \\
(0.66)\end{array}$ \\
\hline $\begin{array}{l}\text { Monetary value of amendments } \\
\text { for municipalities (in millions) }\end{array}$ & $\begin{array}{l}4.64 \\
(3.9)\end{array}$ & $\begin{array}{l}4.10 \\
(0.01)\end{array}$ & $\begin{array}{l}4.82 \\
(0.00)\end{array}$ & $\begin{array}{c}-0.72^{* * * *} \\
\quad(0.2)\end{array}$ \\
\hline Age & $\begin{array}{l}49.23 \\
(10.1)\end{array}$ & $\begin{array}{l}50.36 \\
(0.02)\end{array}$ & $\begin{array}{l}48.85 \\
(0.01)\end{array}$ & $\begin{array}{c}1.51^{* * *} \\
(0.51)\end{array}$ \\
\hline Female & $\begin{array}{c}0.07 \\
(0.26)\end{array}$ & $\begin{array}{c}0.08 \\
(0.00)\end{array}$ & $\begin{array}{l}0.07 \\
(0.00)\end{array}$ & $\begin{array}{c}0.01 \\
(0.01)\end{array}$ \\
\hline Undergraduate degree & $\begin{array}{c}0.77 \\
(0.42)\end{array}$ & $\begin{array}{c}0.76 \\
(0.00)\end{array}$ & $\begin{array}{l}0.77 \\
(0.00)\end{array}$ & $\begin{array}{l}-0.01 \\
(0.02)\end{array}$ \\
\hline Number of previous terms & $\begin{array}{l}1.28 \\
(1.46)\end{array}$ & $\begin{array}{l}1.38 \\
(0.00)\end{array}$ & $\begin{array}{l}1.25 \\
(0.00)\end{array}$ & $\begin{array}{l}0.13^{* *} \\
(0.07)\end{array}$ \\
\hline Have been councilor & $\begin{array}{c}0.36 \\
(0.72)\end{array}$ & $\begin{array}{c}0.28 \\
(0.00)\end{array}$ & $\begin{array}{l}0.38 \\
(0.00)\end{array}$ & $\begin{array}{c}-0.1^{* * *} \\
(0.04)\end{array}$ \\
\hline Have been mayor & $\begin{array}{c}0.24 \\
(0.57)\end{array}$ & $\begin{array}{c}0.27 \\
(0.00)\end{array}$ & 0.23 & $\begin{array}{l}0.04^{*} \\
(0.03)\end{array}$ \\
\hline Obs. & 2,052 & 523 & 1,529 & \\
\hline
\end{tabular}

Table 2 Characteristics of municipalities by term.

\begin{tabular}{lcccc}
\hline & 50 th term & 51 st term & 52nd term & $53 \mathrm{rd}$ term \\
\hline Number of effective candidates & 5.74 & 5.54 & 6.08 & 6.52 \\
& $(4.18)$ & $(3.95)$ & $(3.76)$ & $(4.32)$ \\
Number of associated candidates & 5.76 & 5.56 & 6.10 & 6.54 \\
& $(4.21)$ & $(3.97)$ & $(3.77)$ & $(4.33)$ \\
Number of elected associated & 3.49 & 3.64 & 4.20 & 4.44 \\
candidates & $(2.59)$ & $(2.56)$ & $(2.67)$ & $(2.88)$ \\
Value of amendments (in thousands) & 417.46 & 464.53 & 480.97 & 535.2 \\
in the municipality & $(772.91)$ & $(1083.63)$ & $(1614.64)$ & $(3207.72)$ \\
Amendments per voter & 43.04 & 44.49 & 32.50 & 23.41 \\
& $(74.49)$ & $(71.36)$ & $(73.02)$ & $(68.83)$ \\
Electorate & 18,870 & 19,237 & 20,698 & 22,570 \\
& $(118,858)$ & $(125,911)$ & $(132,007)$ & $(140,077)$ \\
Obs. & 5,019 & 5,513 & 5,565 & 5,565 \\
\hline
\end{tabular}

Note: Standard deviations are in parentheses. Values of amendments are in $\mathrm{R} \$$ as of 2010. 
Table 3 Characteristics of elected and non-elected deputies for all candidates and those with only narrow margins of victory.

\begin{tabular}{|c|c|c|c|c|c|c|c|c|c|}
\hline & \multicolumn{3}{|c|}{ All } & \multicolumn{3}{|c|}{ Margin $5 \%$} & \multicolumn{3}{|c|}{ Margin $2.5 \%$} \\
\hline & $\begin{array}{l}\text { Not } \\
\text { elected }\end{array}$ & Elected & Diff. & $\begin{array}{l}\text { Not } \\
\text { elected }\end{array}$ & Elected & Diff. & $\begin{array}{l}\text { Not } \\
\text { elected }\end{array}$ & Elected & Diff. \\
\hline $\begin{array}{l}\text { Number of municipalities } \\
\text { that are associated }\end{array}$ & $\begin{array}{c}3.29 \\
(0.00)\end{array}$ & $\begin{array}{l}41.75 \\
(0.02)\end{array}$ & $\begin{array}{c}-38.46^{* * *} \\
(0.36)\end{array}$ & $\begin{array}{l}26.02 \\
(0.09)\end{array}$ & $\begin{array}{l}30.83 \\
(0.11)\end{array}$ & $\begin{array}{l}-4.81^{* *} \\
(2.12)\end{array}$ & $\begin{array}{c}27.4 \\
(0.17)\end{array}$ & $\begin{array}{c}31.47 \\
(0.2)\end{array}$ & $\begin{array}{l}-4.07^{*} \\
(2.87)\end{array}$ \\
\hline $\begin{array}{l}\text { Number of effective } \\
\text { municipalities }\end{array}$ & $\begin{array}{l}4.55 \\
(0.00)\end{array}$ & $\begin{array}{l}12.74 \\
(0.01)\end{array}$ & $\begin{array}{c}-8.19^{* * *} \\
(0.16)\end{array}$ & $\begin{array}{c}9.72 \\
(0.04)\end{array}$ & $\begin{array}{l}11.63 \\
(0.06)\end{array}$ & $\begin{array}{l}-1.91^{* *} \\
(1.05)\end{array}$ & $\begin{array}{l}10.31 \\
(0.07)\end{array}$ & $\begin{array}{l}11.52 \\
(0.11)\end{array}$ & $\begin{array}{l}-1.21 \\
(1.44)\end{array}$ \\
\hline $\begin{array}{l}\text { Percentage of votes } \\
\text { in electoral district }\end{array}$ & $\begin{array}{c}0.00 \\
(0.00)\end{array}$ & $\begin{array}{c}0.03 \\
(0.00)\end{array}$ & $\begin{array}{c}-0.03^{* * *} \\
(0.00)\end{array}$ & $\begin{array}{c}0.02 \\
(0.00)\end{array}$ & $\begin{array}{c}0.02 \\
(0.00)\end{array}$ & $\begin{array}{c}0.00 \\
(0.00)\end{array}$ & $\begin{array}{c}0.02 \\
(0.00)\end{array}$ & $\begin{array}{c}0.02 \\
(0.00)\end{array}$ & $\begin{array}{c}0.00 \\
(0.00)\end{array}$ \\
\hline Age & $\begin{array}{l}46.76 \\
(0.00)\end{array}$ & $\begin{array}{l}49.26 \\
(0.00)\end{array}$ & $\begin{array}{c}-2.5^{* * *} \\
(0.25)\end{array}$ & $\begin{array}{l}48.74 \\
(0.05)\end{array}$ & $\begin{array}{l}48.66 \\
(0.05)\end{array}$ & $\begin{array}{c}0.08 \\
(0.94)\end{array}$ & $\begin{array}{c}48 \\
(0.08)\end{array}$ & $\begin{array}{l}48.48 \\
(0.08)\end{array}$ & $\begin{array}{l}-0.48 \\
(1.23)\end{array}$ \\
\hline Female & $\begin{array}{c}0.11 \\
(0.00)\end{array}$ & $\begin{array}{c}0.07 \\
(0.00)\end{array}$ & $\begin{array}{c}0.04^{* * *} \\
(0.01)\end{array}$ & $\begin{array}{c}0.08 \\
(0.00)\end{array}$ & $\begin{array}{c}0.07 \\
(0.00)\end{array}$ & $\begin{array}{c}0.01 \\
(0.03)\end{array}$ & $\begin{array}{c}0.08 \\
(0.00)\end{array}$ & $\begin{array}{c}0.05 \\
(0.00)\end{array}$ & $\begin{array}{c}0.03 \\
(0.03)\end{array}$ \\
\hline Obs. & 13,457 & 2,052 & & 207 & 212 & & 121 & 123 & \\
\hline Incumbent in previous term & $\begin{array}{c}0.03 \\
(0.00)\end{array}$ & $\begin{array}{c}0.52 \\
(0.00)\end{array}$ & $\begin{array}{c}-0.49 * * * \\
(0.01)\end{array}$ & $\begin{array}{c}0.36 \\
(0.00)\end{array}$ & $\begin{array}{c}0.38 \\
(0.00)\end{array}$ & $\begin{array}{l}-0.02 \\
(0.06)\end{array}$ & $\begin{array}{c}0.4 \\
(0.01)\end{array}$ & $\begin{array}{c}0.34 \\
(0.01)\end{array}$ & $\begin{array}{c}0.06 \\
(0.07)\end{array}$ \\
\hline $\begin{array}{l}\text { Value of amendments } \\
\text { (in millions) in associated } \\
\text { municipalities in previous term }\end{array}$ & $\begin{array}{c}0.10 \\
(0.00)\end{array}$ & $\begin{array}{c}1.73 \\
(0.00)\end{array}$ & $\begin{array}{c}-1.63^{* * *} \\
(0.03)\end{array}$ & $\begin{array}{l}1.26 \\
(0.01)\end{array}$ & $\begin{array}{c}1.08 \\
(0.01)\end{array}$ & $\begin{array}{c}0.18 \\
(0.24)\end{array}$ & $\begin{array}{c}1.15 \\
(0.02)\end{array}$ & $\begin{array}{c}0.87 \\
(0.02)\end{array}$ & $\begin{array}{c}0.28 \\
(0.27)\end{array}$ \\
\hline Obs. & 10,962 & 1,539 & & 144 & 151 & & 86 & 85 & \\
\hline
\end{tabular}

Table 4 Characteristics of municipalities with zero and one elected associated candidate with a narrow margin of victory of five percent.

\begin{tabular}{lccc}
\hline & $\begin{array}{c}\text { Zero elected associated } \\
\text { candidates }\end{array}$ & $\begin{array}{c}\text { One elected associated } \\
\text { candidate }\end{array}$ & Diff. \\
\hline Electorate & $21,284.44$ & $23,090.62$ & $-1,806.18$ \\
& $(31.67)$ & $(33.91)$ & $(3,245.19)$ \\
Average years of education +25 & 4.24 & 4.26 & -0.02 \\
& $(0.00)$ & $(0.00)$ & $(0.03)$ \\
IDH & 0.71 & $(0.00)$ & 0.00 \\
& $(0.00)$ & 186.26 & $(0.00)$ \\
Per capita income $(\mathrm{R} \$$ as of 2000$)$ & 183.95 & $(0.02)$ & -2.31 \\
& $(0.03)$ & 4,723 & $(2.28)$ \\
Obs. & 3,004 & \\
\hline Note: $*$ indicates that the difference is significant at $* \mathrm{p}<0.10, * * \mathrm{p}<0.05, * * * \mathrm{p}<0.01$. Standard errors are in parentheses.
\end{tabular}


Table 5 Allocation of budget amendments to municipalities. Dependent variable: value of allocated amendments per voter.

\begin{tabular}{|c|c|c|c|c|c|}
\hline & OLS 1 & OLS 2 & FE 1 & FE 2 & Tobit \\
\hline Vote percentage in the municipality & $\begin{array}{l}37.773^{* * *} \\
(0.781)\end{array}$ & $\begin{array}{l}38.134^{* * *} \\
(0.787)\end{array}$ & $\begin{array}{l}38.039^{* * *} \\
(0.786)\end{array}$ & $\begin{array}{l}38.963^{* * *} \\
(1.785)\end{array}$ & $\begin{array}{l}32.237^{* * *} \\
(0.234)\end{array}$ \\
\hline Number of effective candidates & & $\begin{array}{l}-0.021^{* * *} \\
(0.003)\end{array}$ & $\begin{array}{l}-0.005 \\
(0.004)\end{array}$ & $\begin{array}{l}-0.022^{* * *} \\
(0.003)\end{array}$ & $\begin{array}{l}0.144^{* * *} \\
(0.006)\end{array}$ \\
\hline Number of effective municipalities & & $\begin{array}{l}-0.018^{* * *} \\
(0.001)\end{array}$ & $\begin{array}{l}-0.018^{* * *} \\
(0.001)\end{array}$ & $\begin{array}{l}-0.023^{* * *} \\
(0.008)\end{array}$ & $\begin{array}{l}-0.035^{* * *} \\
(0.002)\end{array}$ \\
\hline Constant & $\begin{array}{l}29.648^{* * *} \\
(3.022)\end{array}$ & $\begin{array}{l}29.722^{* * *} \\
(3.020)\end{array}$ & $\begin{array}{l}1.132 \\
(1.208)\end{array}$ & $\begin{array}{l}7.244 \\
(4.772)\end{array}$ & $\begin{array}{l}-2.969 \\
(1.502)\end{array}$ \\
\hline Obs. & 683,125 & 683,125 & 683,125 & 683,125 & 683,126 \\
\hline R-squared & 0.100 & 0.100 & 0.067 & 0.068 & - \\
\hline FE Candidate & No & No & No & Yes & No \\
\hline FE Municipality & No & No & Yes & No & No \\
\hline SE Clustered by Candidate & No & No & No & Yes & No \\
\hline SE Clustered by Municipality & Yes & Yes & Yes & No & No \\
\hline
\end{tabular}

Table 6 Discontinuity regression - Allocation of budget amendments to municipalities. Dependent variable: value of amendments per voter.

\begin{tabular}{|c|c|c|c|c|c|c|}
\hline & \multicolumn{3}{|c|}{ Margin $5 \%$} & \multicolumn{3}{|c|}{ Margin $2.5 \%$} \\
\hline & All & $\begin{array}{l}\text { CandEfet } \\
\leq 5\end{array}$ & $\begin{array}{l}\text { CandEfet } \\
>5\end{array}$ & All & $\begin{array}{l}\text { CandEfet } \\
\leq 5\end{array}$ & $\begin{array}{l}\text { CandEfet } \\
>5\end{array}$ \\
\hline $\begin{array}{l}\text { Number of elected associated } \\
\text { candidates }\end{array}$ & $\begin{array}{l}3.4^{* * *} \\
(1.2)\end{array}$ & $\begin{array}{l}4.9^{* * *} \\
(1.8)\end{array}$ & $\begin{array}{l}2.2 \\
(1.8)\end{array}$ & $\begin{array}{l}3.7^{* * *} \\
(1.2)\end{array}$ & $\begin{array}{l}5.8^{* * *} \\
(2.2)\end{array}$ & $\begin{array}{l}2.0 \\
(1.6)\end{array}$ \\
\hline Number of effective candidate & $\begin{array}{l}-1.4^{* * * *} \\
(0.2)\end{array}$ & $\begin{array}{l}-4.5^{* * *} \\
(1.1)\end{array}$ & $\begin{array}{l}-1.2^{* * *} \\
(0.3)\end{array}$ & $\begin{array}{l}-1.3^{* * *} \\
(0.3)\end{array}$ & $\begin{array}{l}-4.0^{* * *} \\
(1.4)\end{array}$ & $\begin{array}{l}-1.2^{* * * *} \\
(0.2)\end{array}$ \\
\hline $\begin{array}{l}\text { Number of elected candidates } \\
\text { that have been mayor }\end{array}$ & $\begin{array}{l}-9.1^{*} \\
(5.0)\end{array}$ & $\begin{array}{l}-4.6 \\
(7.8)\end{array}$ & $\begin{array}{l}-6.6 \\
(7.2)\end{array}$ & $\begin{array}{l}-9.5 \\
(6.9)\end{array}$ & $\begin{array}{l}-5.5 \\
(10.3)\end{array}$ & $\begin{array}{l}-3.7 \\
(9.1)\end{array}$ \\
\hline Number of elected candidates & -6.3 & 4.2 & -7.4 & -3.2 & 1.3 & -3.8 \\
\hline that have been councilor & $(6.9)$ & $(10.3)$ & $(7.2)$ & $(6.9)$ & $(16.4)$ & $(7.4)$ \\
\hline Constant & $54.1^{* * *}$ & $50.8^{* *}$ & $74.2^{* * *}$ & $56.9^{* * *}$ & $49.5^{*}$ & $71.6^{* * *}$ \\
\hline & $(10.1)$ & $(20.8)$ & $(12.8)$ & $(12.1)$ & $(27.7)$ & $(13.7)$ \\
\hline Obs. & 8,559 & 3,723 & 4,836 & 5,734 & 2,347 & 3,387 \\
\hline R-squared & 0.30 & 0.22 & 0.35 & 0.33 & 0.20 & 0.43 \\
\hline
\end{tabular}

Note: $* \mathrm{p}<0.10,{ }^{*} \mathrm{p}<0.05, * * * \mathrm{p}<0.01$. Robust standard errors are in parentheses. Dummies for elections and state are considered in all models. The following variables are used as controls: number of associated candidates who are members of mayor's party, party is the same as the governor's party, party is the same as the president's party, mean of associated candidates' effective municipality and electorate. Amendments are reported in $\mathrm{R} \$$ as of 2010 . 
Table 7 Impact of budget amendments on the number of votes. Dependent variable: nominal votes for deputies in the municipality.

\begin{tabular}{|c|c|c|c|c|c|c|}
\hline & OLS 1 & OLS 2 & FE 1 & FE 2 & FE 3 & FE 4 \\
\hline Amendment by voter & $\begin{array}{l}4.631^{* * *} \\
(0.915)\end{array}$ & $\begin{array}{l}6.694^{* * *} \\
(0.910)\end{array}$ & $\begin{array}{l}7.050^{* * *} \\
(0.820)\end{array}$ & $\begin{array}{l}7.807^{* * *} \\
(0.876)\end{array}$ & $\begin{array}{l}5.948^{* * *} \\
(0.451)\end{array}$ & \\
\hline Amendment by voter ${ }^{2}$ & & $\begin{array}{l}-0.003^{* * *} \\
(0.001)\end{array}$ & $\begin{array}{l}-0.004^{* * *} \\
(0.001)\end{array}$ & $\begin{array}{l}-0.004^{* * *} \\
(0.001)\end{array}$ & $\begin{array}{l}-0.008^{* * *} \\
(0.001)\end{array}$ & \\
\hline $\begin{array}{l}\text { Amendment by voter } \\
\text { municipalities the deputy } \\
\text { is associated }\end{array}$ & & & & & & $\begin{array}{l}5.369^{* * *} \\
(0.547)\end{array}$ \\
\hline $\begin{array}{l}\text { Amendment by voter } \\
\text { municipalities the deputy } \\
\text { is associated }{ }^{2}\end{array}$ & & & & & & $\begin{array}{l}-0.008^{* * *} \\
(0.001)\end{array}$ \\
\hline $\begin{array}{l}\text { Amendment by voter } \\
\text { municipalities the deputy } \\
\text { is NOT associated }\end{array}$ & & & & & & $\begin{array}{l}7.371^{* * *} \\
(0.630)\end{array}$ \\
\hline $\begin{array}{l}\text { Amendment by voter } \\
\text { municipalities the deputy } \\
\text { is NOT associated }{ }^{2}\end{array}$ & & & & & & $\begin{array}{l}-0.010^{* * *} \\
(0.003)\end{array}$ \\
\hline $\begin{array}{l}\text { Deputy was associated } \\
\text { with the municipality } \\
\text { in previous election }\end{array}$ & $\begin{array}{l}1,071.394^{* * *} \\
(66.794)\end{array}$ & $\begin{array}{l}1,061.512^{* * *} \\
(67.378)\end{array}$ & $\begin{array}{l}1,056.225^{* * *} \\
(32.952)\end{array}$ & $\begin{array}{l}1,032.365^{* * *} \\
(65.312)\end{array}$ & $\begin{array}{l}-52.353^{* * *} \\
(9.980)\end{array}$ & $\begin{array}{l}-47.851^{* * *} \\
(10.120)\end{array}$ \\
\hline Constant & $\begin{array}{r}-409.617^{*} \\
(218.473)\end{array}$ & $\begin{array}{l}-463.436^{* *} \\
(218.848)\end{array}$ & $\begin{array}{l}-62.919 \\
(68.205)\end{array}$ & $\begin{array}{l}15.511 \\
(26.497)\end{array}$ & $\begin{array}{l}175.414^{* *} \\
(86.344)\end{array}$ & $\begin{array}{l}175.740^{* *} \\
(86.356)\end{array}$ \\
\hline Observations & 526,025 & 526,025 & 526,025 & 526,025 & 310,306 & 310,306 \\
\hline R-squared & 0.348 & 0.349 & 0.328 & 0.138 & 0.017 & 0.017 \\
\hline FE deputy & No & No & Yes & No & No & No \\
\hline FE municipality & No & No & No & Yes & No & No \\
\hline FE deputy-municipality & No & No & No & No & Yes & Yes \\
\hline
\end{tabular}

Table 8 Relationship between budget amendments and electoral success. Dependent variable: success or failure in reelection effort.

\begin{tabular}{|c|c|c|c|c|}
\hline & Probit 1 & Probit 2 & Probit 3 & Probit 4 \\
\hline Amendment by voter & $\begin{array}{l}0.003^{*} \\
(0.002)\end{array}$ & $\begin{array}{l}0.001 \\
(0.009)\end{array}$ & & \\
\hline Amendment by voter ${ }^{2}$ & & $\begin{array}{l}0.000 \\
(0.000)\end{array}$ & & \\
\hline $\begin{array}{l}\text { Amendment by voter municipalities } \\
\text { the deputy is associated } \\
\text { Amendment by voter municipalities } \\
\text { the deputy is associated }{ }^{2}\end{array}$ & & & $\begin{array}{l}0.004 \\
(0.003)\end{array}$ & $\begin{array}{l}0.019 \\
(0.016) \\
-0.000 \\
(0.000)\end{array}$ \\
\hline $\begin{array}{l}\text { Amendment by voter municipalities } \\
\text { the deputy is NOT associated } \\
\text { Amendment by voter municipalities } \\
\text { the deputy is NOT associated }\end{array}$ & & & $\begin{array}{l}-0.009 \\
(0.010)\end{array}$ & $\begin{array}{l}-0.069^{* * *} \\
(0.020) \\
0.003^{* * *} \\
(0.001)\end{array}$ \\
\hline Obs. & 1,520 & 1,520 & 1,520 & 1,520 \\
\hline Pseudo R-squared & 0.0669 & 0.0670 & 0.0676 & 0.0734 \\
\hline
\end{tabular}

Note: ${ }^{*} \mathrm{p}<0.10,{ }^{* *} \mathrm{p}<0.05, * * * \mathrm{p}<0.01$. Standard errors, clustered at state level, are in parentheses. Reported coefficients refer to marginal effects. Dummies for elections, party and state are considered in all models. The following variables are used as controls: Value of national, regional and state amendments; number of effective municipalities; number of councilor mandates; number of mayor mandates; party is the same as the governor's party; party is the same as the president's party; number of previous legislatures; number of state deputy mandates; number of governor mandates; number of senator mandates; undergraduate degree; dummy for being a woman; and state electorate. Amendments are reported in $\mathrm{R} \$$ as of 2010 . 
Table A1 Overall amendment values by deputies' association status (at municipal level).

\begin{tabular}{|c|c|c|c|c|c|}
\hline \multicolumn{6}{|c|}{ Total of amendment from elected NOT associated candidates } \\
\hline & Median & Mean & Std Dev & Obs. & \\
\hline 50 th term & 0.0 & $99,707.9$ & $278,867.4$ & & 5,019 \\
\hline 51st term & 0.0 & $118,906.4$ & $394,318.1$ & & 5,513 \\
\hline 52nd term & 0.0 & $137,478.3$ & $576,932.9$ & & 5,565 \\
\hline 53 rd term & 0.0 & $136,004.9$ & $1,038,234.7$ & & 5,565 \\
\hline \multicolumn{6}{|c|}{ Total of amendment from elected associated candidates } \\
\hline & Median & Mean & Std Dev & Obs. & \\
\hline 50 th term & $116,115.0$ & $274,027.2$ & $585,892.4$ & & 5,019 \\
\hline 51st term & $122,061.5$ & $307,976.9$ & $819,991.8$ & & 5,513 \\
\hline $52 \mathrm{nd}$ term & 0.0 & $309,711.4$ & $1,145,345.0$ & & 5,565 \\
\hline 53rd term & 0.0 & $367,857.6$ & $2,280,778.5$ & & 5,565 \\
\hline
\end{tabular}

Note: Values of amendments are in $\mathrm{R} \$$ as of 2010.

Table A2 Robustness checks - Different formulations for candidate association

\begin{tabular}{|c|c|c|c|c|c|c|}
\hline & \multicolumn{6}{|c|}{ Associated $=0.5^{*}$ Effect Candidate } \\
\hline & \multicolumn{3}{|c|}{ Margin $5 \%$} & \multicolumn{3}{|c|}{ Margin $2.5 \%$} \\
\hline & All & $\begin{array}{l}\text { CandEfet } \\
\leq 5\end{array}$ & $\begin{array}{l}\text { CandEfet } \\
>5\end{array}$ & All & $\begin{array}{l}\text { CandEfet } \\
\leq 5\end{array}$ & $\begin{array}{l}\text { CandEfet } \\
>5\end{array}$ \\
\hline $\begin{array}{l}\text { Number of elected } \\
\text { associated candidates }\end{array}$ & $\begin{array}{l}5.3^{* *} \\
(2.1)\end{array}$ & $\begin{array}{l}12.6^{* * *} \\
(2.4)\end{array}$ & $\begin{array}{l}1.6 \\
(2.8)\end{array}$ & $\begin{array}{l}4.2^{* *} \\
(2.0)\end{array}$ & $\begin{array}{l}13.4^{* * *} \\
(2.7)\end{array}$ & $\begin{array}{l}-0.2 \\
(2.7)\end{array}$ \\
\hline Number of effective & $-1.1^{* * *}$ & $-4.7 * * *$ & $-1.1^{* * *}$ & $-0.9^{* * *}$ & $-3.8^{* *}$ & $-1.2^{* * *}$ \\
\hline candidate & $(0.2)$ & $(1.4)$ & $(0.3)$ & $(0.3)$ & $(1.7)$ & $(0.4)$ \\
\hline Constant & $\begin{array}{l}58.2^{* * *} \\
(6.7)\end{array}$ & $\begin{array}{l}71.8^{* * *} \\
(9.8)\end{array}$ & $\begin{array}{l}62.3^{* * *} \\
(11.9)\end{array}$ & $\begin{array}{l}44.4^{* * *} \\
(9.4)\end{array}$ & $\begin{array}{l}32.8^{* * *} \\
(9.8)\end{array}$ & $\begin{array}{l}71.8^{* * *} \\
(16.5)\end{array}$ \\
\hline Obs. & 4,810 & 1,759 & 3,051 & 3,029 & 1,028 & 2,001 \\
\hline \multirow[t]{4}{*}{ R-squared } & 0.3 & 0.3 & 0.4 & 0.4 & 0.3 & 0.4 \\
\hline & \multicolumn{6}{|c|}{ Associated $=1.5^{*}$ Effect Candidate } \\
\hline & \multicolumn{3}{|c|}{ Margin $5 \%$} & \multicolumn{3}{|c|}{ Margin $2.5 \%$} \\
\hline & All & $\begin{array}{l}\text { CandEfet } \\
\leq 5\end{array}$ & $\begin{array}{l}\text { CandEfet } \\
>5\end{array}$ & All & $\begin{array}{l}\text { CandEfet } \\
\leq 5\end{array}$ & $\begin{array}{l}\text { CandEfet } \\
>5\end{array}$ \\
\hline Number of elected & $3.5^{* * *}$ & $4.8^{* * *}$ & $2.5^{*}$ & $3.6^{* * *}$ & $5.4^{* * *}$ & $2.6^{*}$ \\
\hline associated candidates & $(1.0)$ & $(1.5)$ & $(1.4)$ & $(1.0)$ & $(1.7)$ & $(1.4)$ \\
\hline Number of effective & $-1.4^{* * *}$ & $-4.1^{* * *}$ & $-1.1^{* * *}$ & $-1.3^{* * *}$ & $-3.9^{* * *}$ & $-1.1^{* * *}$ \\
\hline candidate & $(0.2)$ & $(1.0)$ & $(0.2)$ & $(0.2)$ & $(1.2)$ & $(0.2)$ \\
\hline Constant & $77.8^{* * *}$ & $94.2^{* * *}$ & $68.3^{* * *}$ & $89.8^{* * *}$ & $116.2^{* * *}$ & $62.5^{* * *}$ \\
\hline Obs. & 10,876 & 4,817 & 6,059 & 7,566 & 3,128 & 4,438 \\
\hline R-squared & 0.3 & 0.2 & 0.3 & 0.3 & 0.2 & 0.4 \\
\hline
\end{tabular}

Note: $* \mathrm{p}<0.10, * * \mathrm{p}<0.05, * * * \mathrm{p}<0.01$. Robust standard errors are in parentheses. Dummies for elections and state are considered in all models. The following variables are used as controls: number of associated candidates who are members of mayor's party, party is the same as the governor's party, party is the same as the president's party, mean of associated candidates' effective municipality and electorate. Amendments are reported in $\mathrm{R} \$$ as of 2010 . 
Table A3 Robustness checks - Different formulations for candidate association

\begin{tabular}{|c|c|c|}
\hline & $\begin{array}{c}\text { Associado }=0.5^{*} \text { CandEfet } \\
\text { FE }\end{array}$ & $\begin{array}{c}\text { Associado }=1.5^{*} \text { CandEfet } \\
\text { FE }\end{array}$ \\
\hline $\begin{array}{l}\text { Amendment by voter } \\
\text { municipality the deputy is associated }\end{array}$ & $\begin{array}{l}5.770 * * * \\
(0.661)\end{array}$ & $\begin{array}{c}5.476 * * * \\
(0.533)\end{array}$ \\
\hline $\begin{array}{l}\text { Amendment by voter } \\
\text { municipality the deputy is associated }{ }^{2}\end{array}$ & $\begin{array}{c}-0.008 * * * \\
(0.001)\end{array}$ & $\begin{array}{c}-0.008 * * * \\
(0.002)\end{array}$ \\
\hline $\begin{array}{l}\text { Amendment by voter } \\
\text { municipality the deputy is NOT associated }\end{array}$ & $\begin{array}{c}6.228^{* * *} \\
(0.652)\end{array}$ & $\begin{array}{l}7.458^{* * *} \\
(0.637)\end{array}$ \\
\hline $\begin{array}{l}\text { Amendment by voter } \\
\text { municipality the deputy is NOT } \text { associated }^{2}\end{array}$ & $\begin{array}{c}-0.010^{* * *} \\
(0.003)\end{array}$ & $\begin{array}{c}-0.010^{* * *} \\
(0.003)\end{array}$ \\
\hline $\begin{array}{l}\text { Deputy was associated to } \\
\text { municipality in previous election }\end{array}$ & $\begin{array}{l}-74.128 * * * \\
\quad(25.257)\end{array}$ & $\begin{array}{l}-31.604^{* * *} \\
(7.942)\end{array}$ \\
\hline Constant & $\begin{array}{c}175.297^{* *} \\
(86.425)\end{array}$ & $\begin{array}{c}175.352^{* *} \\
(86.359)\end{array}$ \\
\hline Observations & 310,306 & 310,306 \\
\hline R-squared & 0.017 & 0.017 \\
\hline FE deputy & No & No \\
\hline FE municipality & No & No \\
\hline FE deputy-municipality & Yes & Yes \\
\hline \multicolumn{3}{|c|}{$\begin{array}{l}\text { Note: * } \mathrm{p}<0.10, * * \mathrm{p}<0.05, * * * \mathrm{p}<0.01 \text {. Clustered standard errors are in parentheses. Clusters are at the fixed effect level in FE } \\
\text { model. Dummies for elections, party and state are considered in all models. The following variables are used as controls: number } \\
\text { of councilor mandates in municipality, number of mayor mandates in municipality, party is the same as the mayor's party, party } \\
\text { is the same as the governor's party, party is the same as the president's party, number of previous legislatures, number of state } \\
\text { deputy mandates, number of governor mandates, number of senator mandates, undergraduate degree, dummy for being a woman, } \\
\text { dummy for state capital and electorate. Amendments are reported in } \mathrm{R} \$ \text { as of } 2010 \text {. }\end{array}$} \\
\hline
\end{tabular}

Table A4 Robustness checks - Different formulations for candidate association

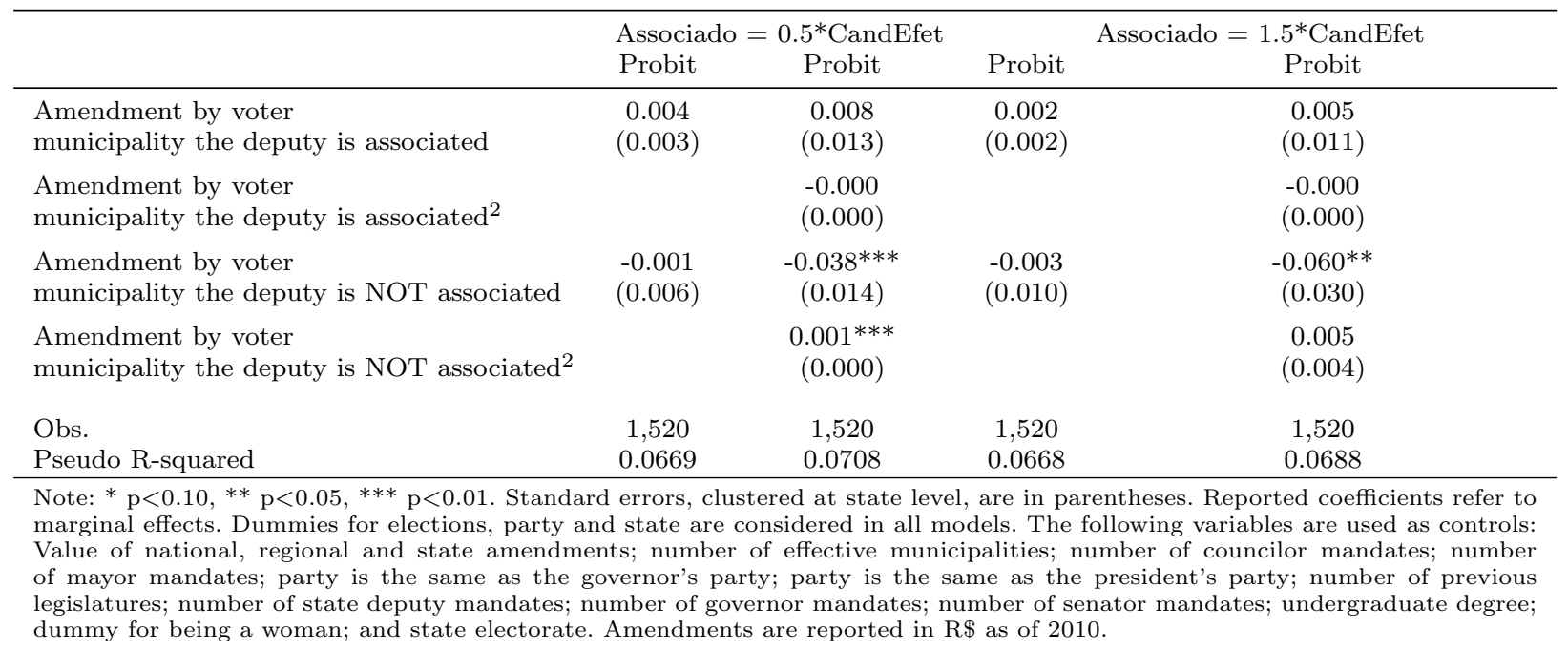




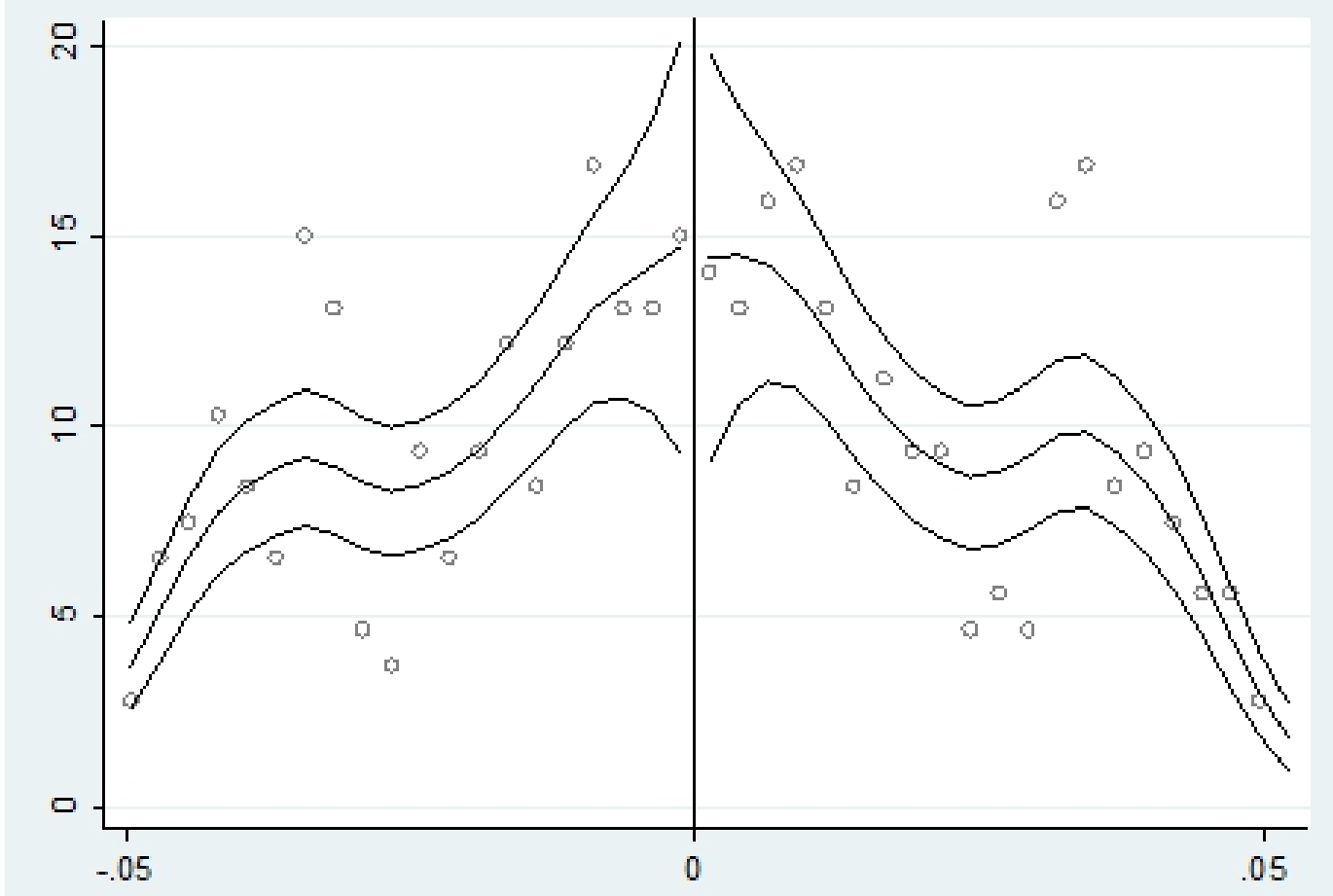

Fig. A1 (Densities and their 95\% confidence intervals of intra-party coalition vote share for non-elected (negative) and elected deputies (positive $\mathrm{x}$ axis)) 